\title{
PENGOLAHAN KASET REKAMAN VIDEO: STUDI KASUS DI PUSAT DOKUMENTASI VIDEO JOGJA TV ${ }^{1}$
}

\author{
Muhammad Bahrudin \\ Departemen Ilmu Perpustakaan dan Informasi, Fakultas Ilmu Pengetahuan Budaya \\ Universitas Indonesia, Depok 16424, Indonesia \\ Email:m.ambar.bahr@gmail.com
}

\begin{abstract}
Abstrak
Penelitian ini membahas tentang pengolahan koleksi rekaman video di Pusat Dokumentasi Jogja TV. Tujuannya adalah untuk mengidentifikasi pengelolaan koleksi rekaman video di pusat dokumentasi tersebut dan kekhasan dari sistem yang diterapkan. Penelitian ini adalah penelitian kualitatif deskriptif dengan desain studi kasus. Pengumpulan data dilakukan dengan cara observasi dan wawancara dengan beberapa informan. Hasil penelitian ini menyarankan agar perlu adanya upgrade dari sistem yang diterapkan dan pengindeksan subyek yang terawasi oleh sebuah authority control untuk memudahkan proses temu kembali informasinya.
\end{abstract}

\begin{abstract}
This study discusses the processing of video recording collections in Pusat Dokumentasi Video Jogja TV. The objectives are identification management video recording collections in there and special characteristic of the system has been applied. This is qualitative-descriptive research with a case study design. Data were collected by observation and interview with the related informants. Findings of this study was suggesting for upgrading the system has been applied and the need for being subject indexing that controlled by the authority control. It will make an easy way for the information retrieval process.
\end{abstract}

Keywords: video cassette recording, indexing, authority control, information retrieval, documentation

\footnotetext{
${ }^{1}$ Artikel ini merupakan versi ringkas dari Skripsi dengan judul yang sama sebagai prasyarat meraih gelar Sarjana di Program Studi Ilmu Perpustakaan, Departemen Ilmu Perpustakaan dan Informasi, Fakultas Ilmu Pengetahuan Budaya, Universitas Indonesia, tahun 2013
} 


\section{Pendahuluan}

Perkembangan media televisi di Indonesia kini semakin pesat di era keterbukaan informasi. Media televisi yang sebelumnya banyak dibatasi dalam hal penayangan informasi dan program acaranya, kini semakin terbuka. Arus informasi dapat mengalir bebas kepada masyarakat melalui berbagai media, baik cetak maupun elektronik. Disahkannya Undang-Undang No. 32 tahun 2002 tentang Penyiaran memicu tumbuhnya stasiun televisi di Indonesia khususnya stasiun televisi swasta, baik di tingkat nasional maupun di tingkat lokal (daerah).

Data dari Komisi Penyiaran Indonesia menyebutkan bahwa pada tahun 2012 tercatat ada 12 stasiun televisi nasional di Indonesia. Data itu belum termasuk jumlah stasiun televisi lokal di 33 provinsi di Indonesia yang jumlahnya mencapai 271 stasiun televisi. Jawa Timur tercatat sebagai provinsi yang memiliki stasiun televisi lokal terbanyak di Indonesia dengan 37 stasiun. Data ini menunjukkan perkembangan dunia pertelevisian di Indonesia memang sangat pesat.

Kegiatan penyiaran televisi adalah suatu proses yang kompleks, mulai dari pengambilan gambar, pengeditan, hingga penayangan informasi kepada masyarakat luas. Produk informasi dari suatu stasiun televisi adalah program acara atau program siaran. Setiap program acara di stasiun televisi tentunya menghasilkan bahan dokumentasi sebagai bukti siar. Seiring perkembangan stasiun televisi di penjuru daerah di Indonesia, apakah telah didukung dengan kesadaran pengelolaan dokumentasinya?

Informasi yang disajikan oleh televisi berupa rekaman audio visual. Jurnalis televisi memanfaatkan kaset video sebagai media perekaman informasi di lapangan yang selanjutnya akan ditransmisikan kembali melalui stasiun televisi agar dapat dinikmati oleh khalayak luas. Penggunaan kaset video ini berlangsung terus menerus di suatu stasiun televisi sehingga membutuhkan penanganan khusus di pusat dokumentasinya agar ketika akan digunakan dapat dengan cepat ditemukan kembali. Apalagi jika kaset video akan digunakan di masa mendatang, tentu memerlukan suatu sistem pengelolaan kaset video yang baik di pusat dokumentasi tersebut.

Penelitian-penelitian mengenai pengelolaan kaset rekaman video di stasiun televisi umunya menyimpulkan bahwa setiap stasiun televisi memiliki kebijakan tersendiri dalam pengelolaan kaset videonya. Permasalahan sering terjadi berkaitan dengan sumber daya manusia dan juga ketersediaan ruang penyimpanan. Terlepas dari itu, ada juga masalah terkait birokrasi internal di stasiun televisi tersebut yang turut memengaruhi sistem pengelolaan kaset video di pusat dokumentasinya. Ada juga masalah terkait dengan kebijakan penyimpanan dan pelestarian untuk keberlangsungan koleksi kaset video yang juga penting diperhatikan di suatu stasiun televisi. Penelitian itu dilakukan di ranah stasiun televisi nasional dan swasta nasional, seperti RCTI, TVRI, Metro TV, Trans TV, dan SCTV. Sedangkan perkembangan dunia pertelevisian kini telah menjangkau ke daerah-daerah yang kemudian disebut sebagai stasiun televisi lokal. Oleh karena itu, perlu dilakukan penelitian terhadap salah satu stasiun televisi lokal di Indonesia terkait dengan sistem pengelolaan kaset videonya.

Studi ini akan membedah pengelolaan koleksi video di stasiun televisi lokal yaitu Jogja TV. Sebagai stasiun televisi lokal yang telah berdiri hampir 9 tahun, jam tayang 18 jam per hari (pukul 06.00 s.d. 24.00) dan program acara yang sebagian besar ialah inhouse production, tentunya menghasilkan banyak koleksi kaset video yang harus dikelola dengan baik. Staf pusat dokumentasi sendiri kadang mengalami kesulitan dalam penelusuran koleksi berdasarkan topik atau tema tertentu. Hal ini diketahui dari pengamatan lapangan di awal penelitian. Pertanyaan yang ingin dijelaskan dalam studi ini adalah:

1. Bagaimana sistem pengelolaan kaset video di Pusat Dokumentasi Video Jogja TV?

2. Kendala apa saja yang dialami dalam sistem pengelolaan kaset video tersebut?

\section{Metode Penelitian}

Penelitian ini menggunakan pendekatan kualitatif dengan jenis penelitian yaitu deskriptif. Penelitian kualitatif adalah suatu penelitian yang lebih banyak mementingkan proses daripada hasil dan menempatkan peneliti sebagai instrumen utama penelitian. Sedangkan penelitian deskriptif dapat mengungkapkan, menggambarkan atau melukiskan keadaan obyek penelitian pada saat sekarang berdasarkan fakta-fakta yang tampak atau sebagaimana adanya.

Metode penelitian yang digunakan ialah studi kasus dengan mengambil kasus di Pusat Dokumentasi Video Jogja TV terkait dengan pengelolaan kaset videonya. Menurut Surakhmad (1985: 143), studi kasus memusatkan perhatian pada suatu kasus secara intensif 
dan mendetail. Subyek yang diteliti terdiri dari satu unit (atau satu kesatuan unit) yang dipandang sebagai kasus.

Penelitian kualitatif menempatkan manusia dalam posisi penting dalam perolehan data. Manusia dipandang sebagai individu yang memiliki informasi dan tidak hanya sekedar memberikan tanggapan pada apa yang diminta peneliti tetapi juga dapat memilih arah dan selera dalam menyajikan informasi yang mereka miliki. Dalam konteks ini, peneliti bermaksud untuk menggali informasi sebanyak mungkin terkait proses pengelolaan kaset video di Pusat Dokumentasi Video Jogja TV. Oleh karena itu, penelitian ini menggunakan sampel bertujuan (purposive sample). Sampel yang telah terseleksi tersebut kemudian disebut sebagai informan atau narasumber.

Informan dalam penelitian ini berjumlah lima orang, yaitu tiga orang dari staf pusat dokumentasi, seorang dari bagian hubungan masyarakat (humas), dan seorang produser acara. Penentuan informan ini dilakukan dengan mempertimbangan pihak internal dan eksternal. Pihak internal yang dimaksud ialah bahwa harus ada informan dari pihak staf pusat dokumentasi yang mengetahui sistem pengelolaan koleksi kaset rekaman video di dalamnya (tiga orang staf). Tiga orang staf yang dipilih sebagi informan ini masing-masing memegang jabatan utama di pusat dokumentasi, yaitu bagian program, bagian news, dan bagian rushes.

Sedangkan eksternal berarti pihak pengguna (user) yang memanfaatkan layanan yang ada di pusat dokumentasi (dalam hal ini dari bagian humas dan produser acara). Pihak user ini dipilih berdasarkan intensitas pemanfaatan layanan pusat dokumentasi. Hal ini ditentukan dengan cara berdiskusi dengan pihak Jogja TV untuk mengetahui orang-orang yang memiliki intensitas pemanfaatan layanan pusat dokumentasi tinggi. Staf humas, sering memanfaatkan layanan pusat dokumentasi dalam rangka memenuhi permintaan klien, khususnya dari pihak eksternal Jogja TV. Sedangkan produser acara sering memanfaatkan layanan pusat dokumentasi dalam rangka mendapatkan stok-stok gambar yang akan digunakan untuk kebutuhan program acara.

Kegiatan penelitian secara keseluruhan dilakukan sejak awal Maret 2013 untuk observasi, namun baru dilakukan wawancara mendalam mulai akhir Maret hingga pertengahan April 2013 di Kantor Jogja TV. Wawancara dilakukan dengan tatap muka dengan panduan wawancara yang telah disusun. Unsur yang sangat penting dalam proses interaksi antara peneliti dengan informan adalah wawasan dan pengertian sehingga antara pertanyaan dan jawaban dapat sesuai dengan apa yang telah disusun dalam panduan wawancara. Hasil wawancara mendalam berupa data lisan dari informan melalui suatu percakapan tersistematis. Peneliti mengajukan pertanyaan langsung secara ekslusif kepada setiap informan terpilih.

\section{Hasil dan Pembahasan}

PT Yogyakarta Tugu Televisi (kemudian disebut Jogja TV) berlokasi di Jalan Wonosari Km. 9, Sendangtirto, Berbah, Sleman, Yogyakarta. Jogja TV merupakan institusi penyiaran televisi lokal pertama di Yogyakarta dan diresmikan oleh Sri Sultan Hamengkubuwono X pada tanggal 17 September 2004. Jogja TV memiliki Tiga Pilar Utama yaitu pendidikan, budaya dan pariwisata. Dari ketiga pilar utama itulah diharapkan Jogja TV mampu memberikan informasi, hiburan dan kontrol sosial terhadap masyarakat Yogyakarta dan sekitarnya.

Dengan slogan "Tradisi Tiada Henti", Jogja TV hadir di tengah masyarakat sebagai salah satu pilar kekuatan yang ikut melestarikan sekaligus mengembangkan kebudayaan Yogyakarta sebagai daerah istimewa dan daerah-daerah sekitarnya melalui inovasi dalam berbagai program acaranya.

Jogja TV yang tergabung dalam jaringan Indonesia Network, memiliki jam tayang mulai pukul 06.00 s.d. 24.00 WIB setiap harinya. Sesuai dengan Tiga Pilar Utama yang menjadi falsafahnya, Jogja TV menghadirkan program yang bermuatan lokal dengan persentase $\pm 80 \%$. Oleh karena itu, Jogja TV diharapkan mampu memenuhi kebutuhan masyarakat pada informasi dan hiburan dari daerahnya sendiri.

Jogja TV juga merupakan stasiun televisi yang telah mengaplikasikan berbagai kemajuan teknologi informasi dan komunikasi. Awak produksi program maupun pemberitaan Jogja TV bekerja nyaris tanpa pita (tapeless operation system). Sistem yang dioperasikan secara keseluruhan berbasis pada komputer. Maksudnya, mulai dari kebutuhan pengolahan hingga pelaksanaan siaran dilayani dengan server-server komputer yang bekerja simultan. Berkaitan dengan hal tersebut, tentunya Jogja TV memerlukan sumber daya manusia yang kompeten di bidangnya.

Sebagai stasiun televisi lokal, Jogja TV menjadi stasiun televisi yang memiliki struktur organisasi cukup lengkap dan sudah tidak ada lagi dualisme deskripsi kerja antardivisi. Hal ini berdampak positif kepada setiap divisi yang ada. Mereka bisa fokus dalam 
melaksanakan pekerjaannya sesuai target dan tujuan organisasi serta mencerminkan profesionalisme dalam bekerja.

Perkembangan Jogja TV yang semakin pesat diikuti dengan kesadaran pengelolaan bahan dokumentasi yang dihasilkannya. Manajemen Jogja TV berusaha untuk terus menjaga dan merawat dengan baik setiap bahan dokumentasi yang berupa kaset rekaman video program acara dan berita, sehingga ketika akan dimanfaatkan di kemudian hari dapat ditemukan kembali dengan efektif dan efisien. Pengelolaan bahan dokumentasi tersebut dilaksanakan oleh divisi/bagian tersendiri yaitu Pusat Dokumentasi Video Jogja TV.

\section{Pusat Dokumentasi Video Jogja TV}

Pusat dokumentasi video telah ada sejak awal berdirinya Jogja TV dan bertugas mengolah setiap rekaman video dari program acara maupun berita yang telah dan akan ditayangkan untuk kemudian disimpan dan dilestarikan. Fungsi utama pusat dokumentasi video ini adalah sebagai divisi yang mengolah, menyimpan dan mendistribusikan rekaman video dari program acara dan berita Jogja TV. Pusat dokumentasi ini menempati satu ruang di lantai dua seluas $\pm 16 \mathrm{~m}^{2}$, sudah termasuk ruang pengolahan dan penyimpanan. Koleksi rekaman video yang ada hingga saat ini \pm 35 .000 (Mini DV dan DVD).

Pusat Dokumentasi Video Jogja TV memiliki tiga orang staf dengan jam kerja 8 jam per hari dari pukul 08.00 s.d. 16.00 WIB. Tiga orang staf tersebut memiliki deskripsi kerja sebagai berikut:

Bagian program, bertugas mengelola rekaman video dari berbagai program acara yang telah maupun akan ditayangkan oleh Jogja TV, "menurunkan" atau transfer rekaman video program acara yang akan ditayangkan ke bagian master control (MC) dan juga melayani peminjaman koleksi dan permohonan penggandaan (copy) DVD, baik dari pihak internal maupun eksternal.

Bagian rushes program, bertugas mengelola rekaman video program yang masih mentah dari kameramen (bagian produksi) untuk kemudian diburning atau ditransfer langsung ke bagian editing.

Bagian news, bertugas mengelola rekaman video program berita yang telah ditayangkan oleh Jogja TV dan melayani peminjaman dan permohonan penggandaan (copy) DVD koleksi video program berita dari pusat dokumentasi, baik dari pihak internal maupun eksternal.

\section{Pengadaan Koleksi}

Menurut Soetminah (1992), pengadaan koleksi adalah proses menghimpun bahan pustaka yang akan dijadikan koleksi suatu perpustakaan. Suatu perpustakaan dalam melakukan pengadaan bahan pustaka harus melakukan beberapa kegiatan agar dapat berjalan dengan baik. Hamakonda (1987: 7) menyatakan bahwa pengadaan koleksi mencakup tiga kegiatan utama. Pertama, pemilihan atau seleksi bahan pustaka. Kedua, pengadaan bahan pustaka melalui pembelian, tukar menukar, penerimaan hadiah dan penerbitan sendiri oleh perpustakaan. Ketiga, inventarisasi bahan yang telah diadakan. Pengadaan koleksi di Pusat Dokumentasi Jogja TV berasal dari internal dan eksternal.

Pengadaan koleksi dari internal sebagian besar berupa hasil burning DVD video-video yang berasal dari live record untuk rekaman siaran langsung, dari master control (MC) untuk rekaman video yang sudah tayang, master edit dari bagian editing dan rushes dari kameramen. Rushes adalah video mentah atau belum diedit yang berasal langsung dari kameramen. Itu untuk bagian program dan setiap program terdiri dari dua DVD, satu yang berasal dari editing dan satunya berasal dari master control berupa program yang sudah tayang dan sudah dilengkapi iklan dan rolling teks. Sedangkan untuk bagian news, burning DVD dilakukan setelah transfer dari master control yang disimpan di server 3 .

Pusat dokumentasi juga mendapatkan koleksi kaset dan DVD dari pihak eksternal yang biasanya berupa iklan, demo lagu, dan juga program acara tertentu. Ada pula yang berupa hibah atau hadiah dari pihak eksternal, seperti DVD program "Bumiku Hijau”.

Berdasarkan observasi, jenis kaset yang tersedia di pusat dokumentasi adalah sebagai berikut:

- Mini DV (Sony, Panasonic dan Maxell),

- DVD, dan

- Betacam.

\section{Pengolahan Koleksi}

Standar umum yang digunakan dalam pengolahan bahan nonbuku adalah Anglo-American Cataloguing Rules $2^{\text {nd }} E d$. (AACR2) part 1 chapter 7 . Namun, menurut Cullen (1992: 3), AACR2 tidak tepat (atau memang tidak ditujukan) untuk perpustakaan yang koleksinya khusus satu jenis bahan, di mana bahan pustaka tersebut membutuhkan deskripsi yang jauh lebih lengkap dengan tujuan mengidentifikasi suatu adegan singkat dalam rekaman video. Oleh karena itu, 
pengolahan rekaman video di Pusat Dokumentasi Video Jogja TV menggunakan ad hoc system yang dibuat dengan menyesuaikan kebutuhan dan keadaan yang ada di pusat dokumentasi sehingga mudah digunakan, dipahami dan dimengerti oleh semua staf pusat dokumentasi khususnya dan manajemen stasiun televisi tersebut pada umumnya.

Secara umum, Jogja TV adalah stasiun televisi yang dioperasikan dengan sistem berbasis komputer, sehingga dalam kegiatannya pun tidak terlepas dari jaringan komputer antardivisi yang ada. Demikian pula dengan pusat dokumentasi, kegiatan pengolahan koleksi dimulai dengan mengcopy video (yang terdiri dari program dan berita) dari server-server yang ada. Untuk program proses copy video dilakukan dari server komputer master control dan editing. Sedangkan bagian news mengcopy dari server master control di server 3. Proses pengolahan rekaman video di pusat dokumentasi terbagi menjadi dua yaitu untuk program dan news.

\section{Pengolahan Rekaman Video Program}

Proses pengolahan rekaman video program dimulai setelah bagian produksi menyerahkan video programnya ke bagian rushes untuk ditransfer ke komputer rushes. Setelah itu, video mentah dari kameramen produksi tersebut diburning ke dalam bentuk DVD dengan format AVI. Video hasil burning ini diserahkan ke bagian editing. Video dari bagian editing ini akan mengalami dua kemungkinan yaitu langsung disimpan di bagian master control untuk kemudian ditayangkan atau diambil dulu oleh pusat dokumentasi (bagian program) untuk diburning terlebih dahulu baru kemudian dikirimkan ke master control. Lebih jelasnya bisa diperhatikan pada bagan di bawah ini.

Setelah video ditayangkan, pusat dokumentasi mengcopy video tersebut dari komputer server master control untuk diburning ke dalam bentuk DVD dengan format MPEG-2. Jadi, untuk setiap program acara, pusat dokumentasi memiliki dua rekaman yaitu dari editing yang berformat AVI dan dari master control dengan format MPEG-2. Perbedaan antara kedua rekaman tersebut selain formatnya adalah video yang berasal dari master control sudah dilengkapi dengan iklan dan rolling text sedangkan dari editing belum dilengkapi keduanya. Selain itu juga ada rekaman video mentah dari kameramen program yang disebut rushes.

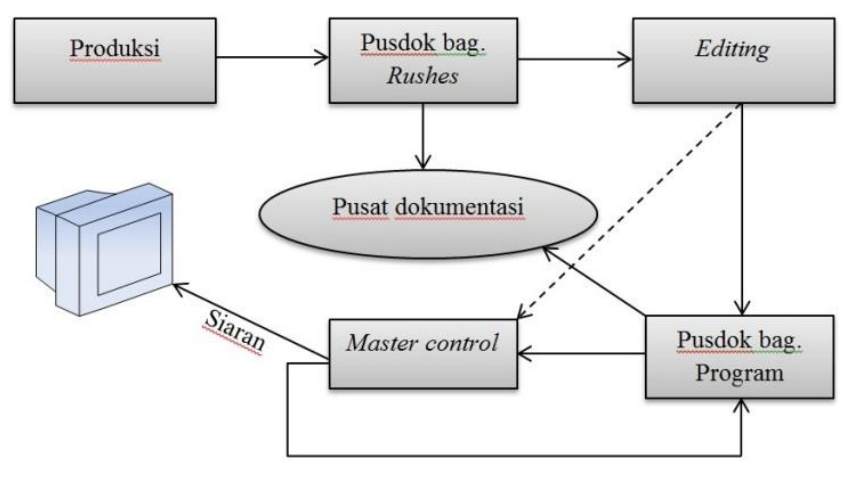

Gambar 1. Alur kerja pengelolaan video program

Setelah proses burning selesai, tahap pengolahan selanjutnya ialah penempelan label mengenai deskripsi isi rekaman video tersebut. Label berisi kode nama program, tanggal tayang dan nomor urut.

Kode klasifikasi yang dilakukan berdasarkan jenis atau nama programnya. Jumlah klasifikasi mengikuti jumlah program yang ada di Jogja TV. Klasifikasi dilakukan hanya untuk koleksi rekaman video sendiri (inhouse production). Sedangkan untuk koleksi yang berasal dari luar (outhouse production) tidak diolah secara khusus dan penyimpanannya pun hanya ditumpuk saja di rak.

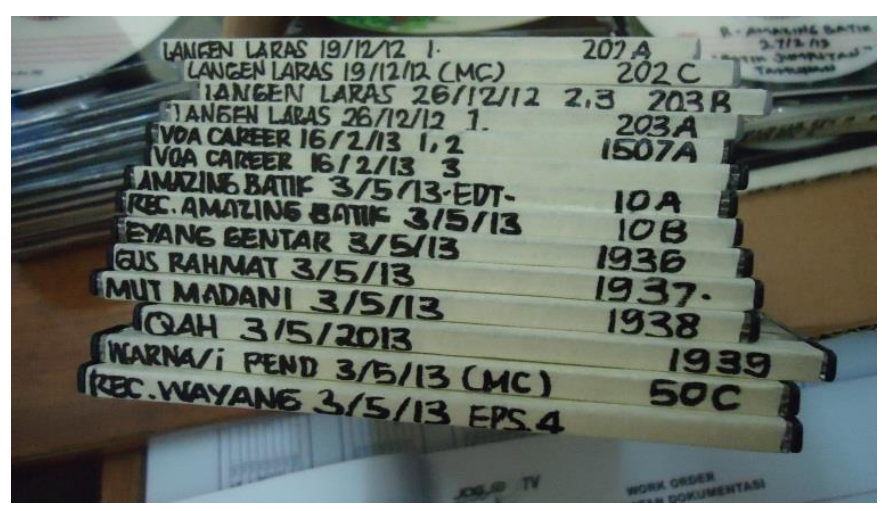

Gambar 2. Penulisan label

Sedangkan untuk penomoran koleksi dilakukan berdasarkan tanggal dan nomor urut DVD per programnya.

Perangkat lunak (software) yang digunakan untuk pengolahan rekaman video program ini adalah Cassette Library Application V.1.0 atau CLA. CLA ini menyediakan menu dan tampilan yang sederhana untuk sebuah sistem pengelolaan database koleksi rekaman video, yaitu: input data, update data, dan tampil data. 


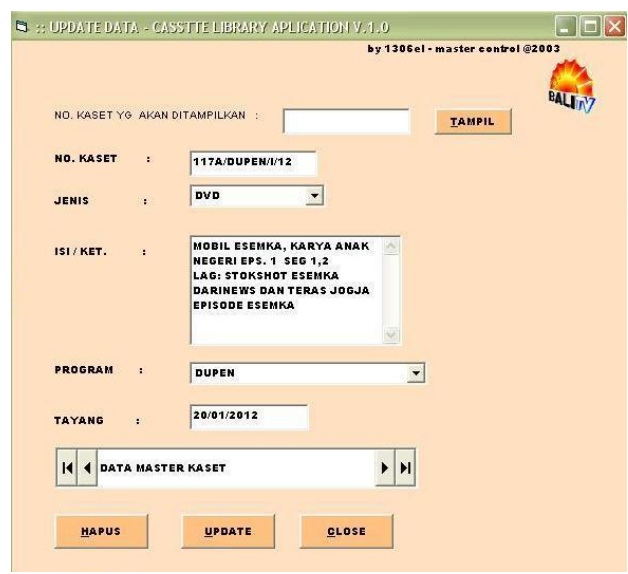

Gambar 3. Tampilan CLA

Pemanfaatan CLA sebagai sistem dalam pengelolaan koleksi rekaman video di Pusat Dokumentasi Video Jogja TV mengaplikasikan pola pengindeksan kata (derivative indexing atau term indexing atau keyword indexing) di mana semua istilah yang ada dalam setiap ruas (field) menjadi indeks yang bisa ditelusur atau dicari. Bahasa yang digunakan dalam sistem ini adalah bahasa alamiah (natural language) yang cakupannya sangat luas dan mutakhir. Dengan kata lain, pengguna bebas menggunakan kata apapun, selama itu ada dalam pangkalan data, untuk menjadi kata kunci penelusuran. Hal ini tentunya lebih memudahkan pengguna dalam proses penelusuran atau pencarian informasi yang dibutuhkannya.

Di setiap rekaman video program yang diambil (copy) oleh pusat dokumentasi, biasanya sudah disertai dengan judul program dan kata kunci. Hal ini adalah kebijakan dari produser. Ketika staf harus menentukan topik (biasanya berupa kata kunci), penentuannya pun hanya berdasarkan gambar-gambar yang ada dalam rekaman tersebut dan tidak ada pedoman terstandar tertentu yang digunakan.

\section{Pengolahan Rekaman Video Berita (News)}

Setelah wartawan liputan, untuk kontributor biasanya langsung ke bagian editor news untuk diedit beritanya. Sedangkan untuk wartawan yang menggunakan kameramen biasanya kameramennya mengolah videonya dulu. Setelah itu, baik dari kameramen maupun editor news, video dikirim ke editor paket untuk diolah menjadi berita. Setelah itu editor paket mengirimkannya ke master control dan disimpen di server 3. Setelah ditayangkan, pusat dokumentasi bagian news akan mengambilnya (copy) melalui komputer server 3 ke komputer di meja kerja bagian news (masih format AVI) untuk kemudian diburning ke dalam DVD dengan format MPEG-2 dan diolah lebih lanjut hingga menjadi koleksi.

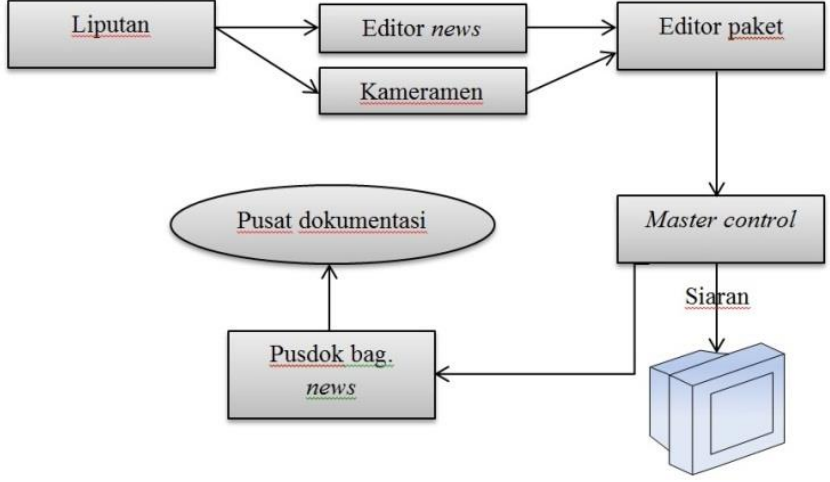

Gambar 4. Alur kerja pengelolaan video berita (news)

Setelah proses burning selesai, tahap selanjutnya adalah penempelan label. Menurut keterangan dari informan, label di DVD berita berisi; kode berita, tanggal tayang, dan nomor urut kaset per program berita.

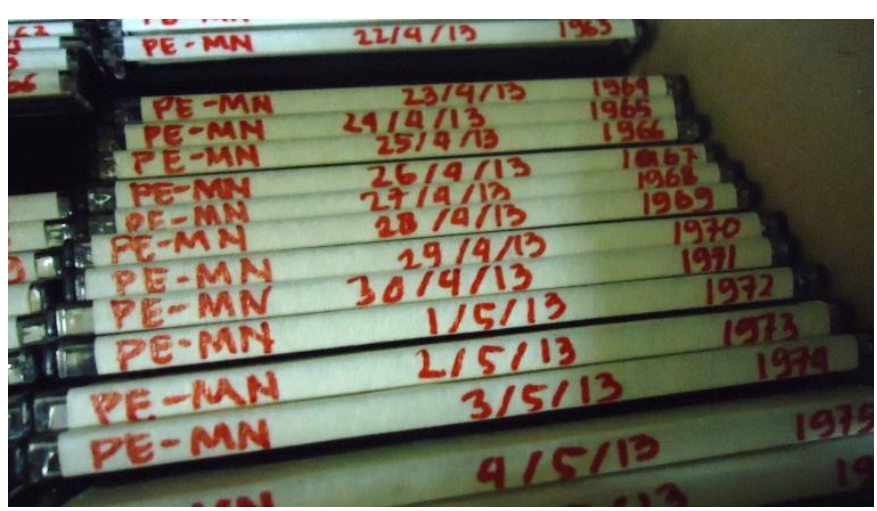

Gambar 5. Label koleksi video berita

Klasifikasi rekaman video berita dilakukan berdasarkan program beritanya. Kode klasifikasi diambil dari singkatan program berita tersebut, seperti SJ-PJ (Seputar Jogja), BM-SJM (Seputar Jogja Malam), GOOD M (Good Morning), PE-MN (Pawartos Enjing) dan PAWARTOS. Sedangkan penomoran dilakukan berdasarkan nomor urut DVD per program berita.

Sistem yang digunakan dalam pengolahan koleksi video program berita, bagian news menggunakan Microsoft Excel. Ruas-ruas (field) yang diisi untuk pangkalan data (database) koleksi rekaman video program berita adalah;

- nomor,

- program berita, tanggal tayang, dan

- judul berita, berisi yang ada di dalam program berita pada tanggal tayang tersebut. 


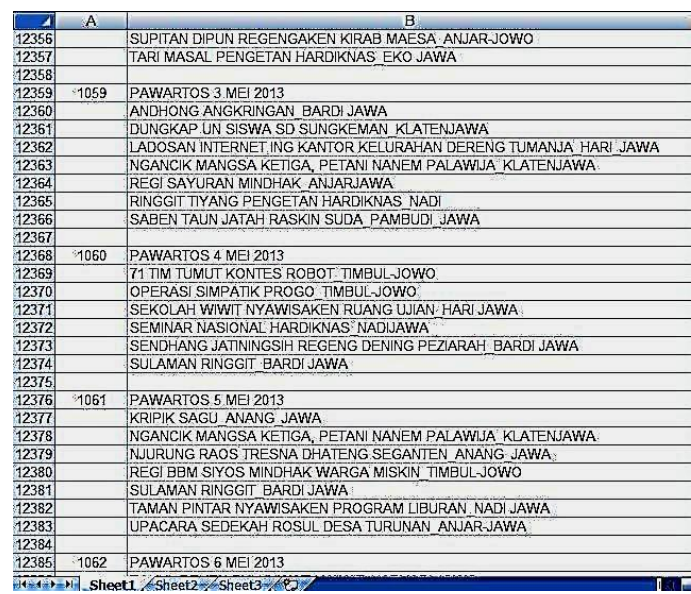

Gambar 6. Database koleksi video berita

Di bagian news tidak ada penulisan kata kunci (keyword), topik atau tema tertentu. Penulisan hanya berupa judul berita yang sudah diberikan oleh redaksi berita (reporternya). Staf pusat dokumentasi hanya tinggal menginput data judul berita tersebut ke dalam database. Masalah yang muncul adalah terkadang ada reporter yang menuliskan judul berita tidak jelas, tidak lengkap atau aneh sehingga menimbulkan kesulitan dalam temu kembalinya. Tanggung jawab mengenai judul berita biasanya sudah melewati bagian editor paket. Editor paket yang nantinya akan mengedit apakah judul berita tersebut perlu diperbaiki atau tidak. Akan tetapi terkadang editor paket pun kurang teliti sehingga masalah judul ini pun tidak terselesaikan.

\section{Deskripsi Bibliografi}

Deskripsi bibliografi yang dilakukan di pusat dokumentasi menggunakan ad hoc system. Tidak ada pedoman khusus yang diaplikasikan dalam tahap ini. Untuk koleksi video program, deskripsi yang dilakukan menyesuaikan dengan ruas (field) yang ada di Cassette Library Application (CLA), yaitu nomor kaset, jenis kaset, isi/keterangan kaset, program dan tanggal tayang. Ruas-ruas tersebut diisi sesuai dengan data yang ada diberikan oleh produser dalam rekaman video tersebut, khususnya pada ruas isi/keterangan. Pada bagian ini yang seharusnya bisa diisi dengan deskripsi yang lebih lengkap. Namun, di pusat dokumentasi ruas tersebut biasanya diisi dengan kata kunci (keyword) yang penulisannya menjadi tanggung jawab produser acara dan bagian editing. Ketika produser atau bagian editing tidak memberikan kata kunci yang tepat dan lengkap, maka deskripsi dari rekaman video tersebut juga tidak maksimal.

Sedangkan deskripsi bibliografi untuk koleksi rekaman video berita, mengaplikasikan prinsip jurnalistik $5 \mathrm{~W}+1 \mathrm{H}$ yang ditemukan oleh Kantor Berita Associated Press pada tahun 1930 (Juyoto, 2001: 29). Berita dianggap secara elementer lengkap bila di dalamnya terdapat unsur-unsur what, who, where, when, why dan how. Prinsip ini menjadi pedoman bagi Pusat Dokumentasi Video Jogja TV bagian news dalam memberikan penamaan file koleksi rekaman video beritanya. Pengaplikasiannya adalah dalam bentuk judul berita dari setiap rekaman video yang ada. Reporter berita menuliskan judul beritanya dan bagian editor paket yang bertugas untuk mengedit apakah judul tersebut sudah relevan terhadap isi berita.

\section{Penyimpanan Koleksi}

Menurut Pearce (1992: 224), kondisi lingkungan yang direkomendasikan untuk koleksi rekaman bervariasi dan sebagian besar koleksi audio visual (kecuali film) bisa terawat dengan baik pada temperatur $20^{\circ} \mathrm{C}$. Berdasarkan observasi peneliti, ruang penyimpanan koleksi di Pusat Dokumentasi Video Jogja TV menyatu dengan meja kerja pengolahan dengan luas $\pm 16 \mathrm{~m}^{2}$ dan sudah dilengkapi dengan satu pendingin ruangan (air conditioner) meskipun tidak menyala selama 24 jam. DVD disimpan dengan kemasannya (cover) dan dimasukkan ke dalam kardus di dalam rak penyimpanan. Penempatan DVD dibedakan berdasarkan program dan news. Rekaman video program disusun berdasarkan tanggal tayang. Sedangkan rekaman video news disusun dengan dikelompokkan lagi berdasarkan program beritanya dan nomor urutnya.

Rak penyimpanan yang digunakan adalah rak besi dan kaca. Rak berbahan besi dan kaca lebih kering dan tahan jamur daripada rak berbahan kayu yang cenderung rawan jamur karena kelembabannya tinggi. Selain itu dari segi keamanan, rak besi lebih tahan terhadap bencana seperti gempa dan kebakaran sehingga kelestarian koleksi bisa terjaga.

\section{Sistem Temu Kembali Informasi}

Temu kembali informasi merupakan kegiatan yang bertujuan untuk menyediakan dan memasok informasi bagi pemakai sebagai jawaban atas permintaan atau berdasarkan kebutuhan pemakai (Sulistyo-Basuki, 1992). Berhasil atau tidaknya temu kembali informasi tergantung dari bagaimana proses deskripi bibliografi hingga tahap entri data ke pangkalan data, baik Casstette Library Application (CLA) maupun Microsoft Excel serta penyusunan koleksi di rak berdasarkan tanggal dan nomor urut.

CLA dan Microsof Excel adalah sistem database yang berbahasa alami atau dengan kata lain menggunakan 
model pengindeksan kata (derivative indexing). Dalam pengindeksan kata, istilah diambil sebagaimana adanya dalam dokumen, menggunakan bahasa alami (natural language), dan cakupan istilahnya tidak selalu jelas. Istilah-istilah yang digunakan mencerminkan perkembangan mutakhir di bidang subyek tersebut. Komputer menetapkan titik temu (access point) dengan konsisten lewat istilah yang ada dalam judul atau bagian lain dari dokumen yang diindeks. Hubungan antaristilah tidak ditunjukkan, kecuali ada upaya khusus sehingga pengindeksan tidak bersifat otomatis lagi dan memerlukan kemampuan intelektual pada tahap penelusurannya. Pada sistem dengan bahasa alami, akan menimbulkan banyak dokumen yang tidak relevan ikut terjaring. Selain itu, sinonim dan variasi kata perlu ditelusuri untuk memeroleh hasil yang komprehensif.

\section{Pelayanan Koleksi}

Pelayanan yang disediakan oleh Pusat Dokumentasi Video Jogja TV diantaranya meliputi peminjaman, copy DVD dan transfer video.

\section{Peminjaman Kaset/DVD}

Layanan ini lebih ditujukan untuk kalangan internal Jogja TV. Setiap transaksi peminjaman yang berlangsung dicatat di database Microsoft Excel. Akantetapi, tidak menutup kemungkinan kalangan eksternal untuk memanfaatkan layanan ini yang tentunya dengan persetujuan dari manajemen Jogja TV. Dari pihak internal, mereka meminjam koleksi biasanya untuk kepentingan penyiaran seperti penayangan ulang program (re-run) dan memotong video untuk kepentingan program/berita

\section{Layanan Copy DVD}

Layanan penggandaan (copy) DVD ini dimanfaatkan oleh pengguna, baik internal maupun eksternal. Pihak internal memanfaatkannya untuk kepentingan produksi acara dan penyiaran. Sedangkan pihak eksternal biasanya untuk kepentingan bukti kerjasama (sponsor atau klien), akademis, dan umum.

\section{Layanan Transfer Video}

Layanan ini bertujuan untuk menyiapkan video rekaman yang akan ditayangkan oleh Jogja TV. Pusat dokumentasi yang telah mengcopy rekaman video master edit dari editing, kemudian menransfernya ke server komputer master control. Selain penransferan dalam bentuk file yang memang sudah ada di komputer pusat dokumentasi, juga berupa pentransferan isi rekaman video yang sudah dalam bentuk DVD ke komputer master control untuk jadwal tayang hingga satu minggu ke depan. Proses ini selain lebih hemat waktu, juga menjaga koleksi rekaman video yang akan ditayangkan oleh master control tanpa harus berpindahnya koleksi dalam bentuk fisik. Hal itu tentunya bisa mencegah terjadinya kehilangan atau kerusakan koleksi rekaman video.

\section{Kesimpulan}

Dari penelitian yang telah dilakukan, peneliti mendapatkan gambaran mengenai pengelolaan koleksi rekaman video yang ada di Pusat Dokumentasi Jogja TV. Pengelolaan tersebut dimulai dari pengadaan, pengolahan, entri data, penyimpanan hingga temu kembali koleksi. Selain itu peneliti juga mendapatkan gambaran mengenai pelayanan yang terjadi di pusat dokumentasi.

Secara keseluruhan, permasalahan yang terjadi dalam pengelolaan koleksi rekaman video di Pusat Dokumentasi Video Jogja TV sama dengan temuan masalah dalam penelitian-penelitian serupa di ranah stasiun televisi swasta, seperti masalah ketersediaan ruang penyimpanan, kebijakan pengolahan koleksi, birokrasi internal. Hal ini merupakan implikasi bahwa pengelolaan kaset rekaman video di stasiun televisi masih banyak menghadapi masalah, meskipun secara teknis di tiap stasiun televisi berbeda. Selain itu dalam proses pengelolaannya masih ditemukan beberapa kendala yang turut memengaruhi kemudahan akses temu kembali informasi, seperti dalam hal deskripsi bibliografi dan pengindeksan subyek.

Pengindeksan subyek yang belum dilakukan dengan baik dalam sistem pengolahan koleksi rekaman video di Pusat Dokumentasi Video Jogja TV tanpa disadari oleh staf-staf terkait, telah menimbulkan kesulitan dalam temu kembali informasinya. Database yang digunakan berbasis free-text di mana setiap ruas dalam database bisa dijadikan titik temu dalam proses temu kembali. Namun tanpa adanya pengindeksan subyek yang baik serta pengawasan atau kontrol terhadap istilah-istilah dalam bahasa alamiah (authority control) seperti sinonim dan sintaksis, bisa menghambat dalam temu kembalinya. Oleh karena itu perlu adalnya pengawasan istilah (authority control) dengan menyusun suatu authority file, misalnya daftar tajuk nama orang, badan, dan sebagainya.

\section{Daftar Acuan}

Anglo-american cataloguing rules ( $2^{\text {nd }}$ ed.). (2002). Chicago: America Library Association 
Company profile Jogja TV. (2012). Yogyakarta: PT Yogyakarta Tugu Televis

Cullen. P. (1992). Recorded sources visual and audio: Non-standard collection management. Aldershot: Ashgate

Fothergill, R., \& Butchart, I. (1990). Non-book materials in library: A practical guide ( $3^{\text {rd }}$ ed.). London: Library Association Publishing Limited

Hamakonda, P. Towa. (1987). Pembinaan koleksi perpustakaan perguruan tinggi. Jakarta: Gramedia

Juyoto, D. (2001). Jurnalistik praktis: Sarana penggerak lapangan kerja raksasa. Yogyakarta: Nur Cahaya

Moleong, L. J. (2005). Metodologi penelitian kualitatif. Bandung: Remaja Rosdakarya

Pearce. M. (1992). Non-standard collection management. Michigan: Ashgate

Soetminah. (1992). Perpustakaan, kepustakawanan dan pustakawan. Jakarta: Kanisius

Sulistyo-Basuki. (1992) Pengantar ilmu perpustakaan. Jakarta: Gramedia Pustaka Utama

Surakhmad, W. (1985). Pengantar penelitian ilmiah: Dasar, metode dan teknik. Bandung: Tarsito 